\title{
Towards The Management And Sustainability Of Farm Related Information Using Geoinformation Technology For Sabon Gari Local Government Area Of Kaduna State-Nigeria
}

\author{
${ }^{1}$ Youngu, T. T., ${ }^{2}$ Aliyu, Y. A., ${ }^{3}$ Sule, J. O. \\ ${ }^{1,2,3}$ Department of Geomatics, Ahmadu Bello University, Zaria-Nigeria
}

\begin{abstract}
In recent times, the world has been experiencing a scarcity in food thereby resulting in a dramatic rise in food prices. One of the ways to tackle this problem is to shift from traditional farming to sustainable farming by investing in research and technology. GPS and GIS technologies were combined to carry out this study. A GPS hand held receiver (Garmin $76 S$ chart plotting receiver) was used to acquire the boundary coordinates (waypoints) of each farmland and attribute data were collected by the use of questionnaire. A database was created using Ms Access 2007 and converted to dbase (IV) format that is compatible with the ArcGIS 9.0 software. The study identified farmland ownership, crops grown, source of irrigation, soil type, farmland yield and access/distribution routes. The database was queried and the results of the queries were analyzed. Simple spatial (distance) analyses were performed to provide an idea of the proximity of the farmland to roads and rail tracks (means of farmland produce distribution) that transverse it. There were 15 farmlands mapped with a total size of 649.42 hectares. The River Kubani was found to be a major source of irrigation for the farmlands along it, and by which, the latter can be related to the concept of Fadama. This can be linked to the National Fadama Development Project under World Bank financing. The study will help provide timely, consistent and accurate information to decision makers for use in planning for the present and future of agriculture in the local government area.
\end{abstract}

Keywords: Farm Mapping, Fadama, Food Security, Geoinformation Technology, Information Management \& Sustainability

\section{Introduction}

The dramatic rise in world food prices has once again forced hunger to the top of the humanitarian agenda. Aid groups have long been warning about the consequences of trade imbalances and climate change, but food crises in Africa and Asia have finally brought the issue to the front burner. The United Nations [1] reported that 100 million people worldwide are now urgently at risk of not having enough food to eat [2].

Systemic and long-term causes for the world-wide increases in food prices continue to be the subject of debate. Initial causes of the late 2006 price spikes included unseasonable droughts in grain producing nations and rising oil prices. Oil prices further heightened the costs of fertilizers, food transport, and industrial agriculture. Some factors, coupled with falling world food stockpiles have all contributed to the dramatic worldwide rise in food prices. These factors may include structural changes in trade and agricultural production, agricultural price supports and subsidies in developed nations, diversions of food commodities to high input foods and fuel, commodity market speculation, and climate change [3].

Low productivity has its own contributing factors, which are physical, policy-related, institutional, and financial in nature. The availability of arable land is dwindling. More and more farmers work on the ecologically fragile land, and average farm size is diminishing. Also contributing to the low productivity are policies that abolished or weakened the role of key institutional support measures. Such measures include statesupported extension services, marketing boards, and state subsidies for agricultural inputs like seeds, pesticides, herbicides and fertilizers. Farmers are further discouraged by the availability of cheap food products on international markets, due largely to export subsidies in developed countries. According to recent analysis by the Food and Agriculture Organization (FAO) and UNCTAD, these subsidies have been associated with rapidly increasing food imports in developing countries. Indeed, a number of traditionally food exporting developing countries have become net food importers over the past 20 years. Sadly, these countries are the hardest-hit by the current crisis, a crisis made even worse for them by mounting oil prices [1].

Food security is the condition in which everyone has access to sufficient and affordable food; it can relate to a single household or to the global population. The first Millennium Development Goal (MDG) falls short of food security aspirations in seeking only to reduce by half the proportion of the world's population experiencing hunger. Furthermore, governments signing the Millennium Declaration were overriding a commitment made just 4 years earlier at the World Food Summit of 1996 which applied the same target to the 
number of people. Rising population figures mean that 170 million fewer will be targeted by the MDG programme than would otherwise have been the case [2].

In order to produce enough affordable and nutritious food for everyone we must shift global agriculture on to a more equitable and sustainable production base. This means ensuring a fair deal for farmers meeting local and regional needs, whilst also investing in research into farming methods which can protect ecosystems and help tackle climate change. Shifting to sustainable farming will mean investing in research and development to help farmers make the best use of farmland. This means modern farming will be used to enhance local traditional knowledge, while protecting people's right to determine their own food. However, in the process of preparing local level agricultural production planning: climate, hydrology, physiography, crop and cropping pattern are to be considered for a planner and/or decision -maker [4].

Crop yield estimation is very important at the national and regional scale [5]. Because of the population increment there is a growing need for micro-level planning and particularly the demand for crop insurance [5], which increases the need for field level yield statistics. Crop yield estimation has an important role in economy development [6]. These predictions warn the decision makers about potential reduction in crop yields and allow timely import and export decision.

Crop yield estimation in many countries is based on conventional techniques of data collection for crop and yield estimation based on ground-based field reports [7]. These methods are costly, time consuming and are prone to large errors due to incomplete ground observations, leading to poor crop yield assessment and crop area estimations. In most countries the data become available too late for appropriate actions to be taken to avert food shortage. Objective, standardized and possibly cheaper/faster methods that can be used for crop growth monitoring and early crop yield estimation are imperative. Remote sensing data has the potential and the capacity to provide spatial information at global scale; of features and phenomena on earth on an almost realtimebasis. They have the potential not only in identifying crop classes but also of estimating crop yield [8]. For all of these the agricultural decision-makers need a good and comprehensive information system [4].

An information system may be formally defined as a combination of human and technical resources, together with a set of organizing procedures that produces information in support of some managerial requirement. Data are raw collections of fact. Data relating to Land may be acquired and held in alphanumeric form (for example, written in notebooks and surveyors field books), or graphically (for example, as maps or aerial photographs), or digitally (for example, using electronic methods). To become information, the raw data must be processed so that a decision maker can understand it. A land information system gives support to land management by providing information about the land, the resources upon it and the improvements made to it. The operation of a land information system includes the acquisition and assembly of data, their processing, storage, and maintenance, and their retrieval, analysis and dissemination [9].

One of the ways to accomplish this task is the application of a Geographic Information System (GIS), which is playing active role, in spatial problems, like global and regional change. GIS provides facilities to use geographic information to help with decision-making and problem solving. A GIS, however, is not automated decision making system but a tool to query, analyze and produce map in support of the decision making process [10]. In simplest terms, a GIS can be thought of as a spatial database. Firstly, this means that discrete geographic locations on the earth's surface can be stored in computer files as sets of mathematical coordinates. This makes it possible to draw a map on a computer. Secondly, it means that different map files, or layers, of spatial information with common geography can be displayed simultaneously and analyzed with reference to one another. In a map of an agricultural area, one layer might represent the boundaries of the , another the soil types found there, another the local streams, and still another the changes in elevation. The analytical power of a GIS lets one query the system to extract information from multiple layers. For instance, to find the most suitable p-lace to plant a crop, one might identify locations with a particular soil type, lying at a certain elevation, and receiving a specified amount of rainfall. Thirdly, it means that any quantitative information that can be linked to geography can be used in a GIS. Not only can one represent, for example, the locations of toxic waste sites in a given region as points on a map, but can symbolize these points (draw them in different colors, sizes, and shapes) according to any information one has about them, such as the type of waste they store. Fourthly, it means that geographic features and phenomena can be modeled from sample data. A typical example is that of a digital terrain model. Sample elevation data is gathered at various points and the GIS uses this input to create a continuous elevation surface, or, in other words, to build a model of the landscape [11].

However spatial data describe the locations of spatial features, which may be discrete or continuous. Discrete features are individually distinguishable features that do not exist between observations. Discrete features include points (e.g., wells), lines (e.g. roads), and areas (e.g., land use types). Continuous features are features that exist spatially between observations. Examples of continuous features are elevation and precipitation. The locations of spatial features on the Earth's surface are based on a geographic coordinate system with longitude and latitude values, whereas the location of map features are based on a plane coordinate system with $\mathrm{x}-, \mathrm{y}$ - coordinates [12]; [13]. Meanwhile, a database is a collection of data that can be shared by different users. It is a group of records and files that are organized so that there is little or no redundancy [9]. 
Spatial database is the heart of GIS. It contains the data or structured spatial data, based on vector; tessellation or object-oriented data model and implemented by rational, network, hierarchic, object-oriented, objectrelational data structure. In it we have the following structural application [14]:

(i) Location data of object: This can be presented in a vector form, as points, lines, areas and volumes or in a tessellation or object-oriented data model or positional data of object: $\mathrm{x}, \mathrm{y}$, (and z) coordinates or cells defining the location of spatial objects being represented in the database e.g. road, river, city, etc.

(ii) Attributes Data: Observed facts about object on features of an object type or relationship.

(iii) Spatial relationship among the objects: Spatial relationships are explicit association between two or more spatial objects.

In GIS, two views of geographic information are used namely; entity-based models and field-based models. In the entity-based model, geographic information gathers within a spatial object point of the embedding space having the same description. Each object is individually distinguished from others by assigning a unique identity to it. The whole set that is, identity, spatial object and its description constitutes an entity or geographic object as defined previously. In the field-based model, geographic information associates each point in space with one or several attribute values, defined as continuous functions in $\mathrm{x}$ and $\mathrm{y}$. Measures of several phenomena can be collected as attribute values varying with the location in the plane, for example, temperature, height, pressure etc. The concept of object is not taken into consideration in the field-based approach. As a result, this view of space as a continuous field is in contrast with the entity-based model, which identifies set of points (e.g. polygon) as an entity or object [15].

At a time when human population growth is taxing the earth's abundance as never before, natural resource managers are discovering the power of GIS to help them make the crucial decisions they face every day. By putting their spatial data in an integrated system where it can be organized, analyzed, and mapped, they find patterns and relationships that were previously unrecognized. Once an expensive technology favored by research scientists, GIS emerged in the 1990s as the tool of choice in local, state, and national resource agencies around the globe. GIS is helping the development and conservation communities find common ground by providing a framework for the analysis and discussion of resource management issues [11]. This study presents an information system that will aid sound decision making for the proper planning and management of farm related information for Sabon Gari local government area.

\section{Significance Of The Study}

Raising agricultural productivity around the globe is clearly crucial in addressing the substantial increase of both food consumption and land use for non-food purposes. At the national level, it needs to become a priority in development strategies. This study provides a consistent, timely, and accurate data to decision makers for use in planning for the present and future of agricultural land resources in Sabon Gari local government area. It also provides maps and other spatial data to the public, academia, and local, state, and federal governments to assist them in making informed decisions for the best utilization of the farmlands in Nigeria.

\section{Area Of Study}

Sabon Gari Local Government Area is located in Zaria in Kaduna State. It is bordered to the south by Tudun wada bridge, to the east by Zaria dam, to the west by Giwa local government area and to the north by Kaduna-Kano express way. Sabon Gari local government area comprises of eleven wards; these are Angwan Gabas, Angwan Basawa, Angwan Auta Jushi, Angwan Jamaa, Angwan Dogarawa, Angwan Hanwa, Angwan Chikaji, Angwan Samaru, Angwan Bomo, Angwan Zabi and Muchia wards. However, Zaria was a province of the British colony in the northern Nigeria. It lies approximately between $351000 \mathrm{mE}$ to $363000 \mathrm{mE}$ and $1228000 \mathrm{mN}$ to $1237000 \mathrm{mN}$. It has an area of about 22,000 square meters and the 2007 estimated population was 1,018827 . The province, of which a great portion consists of open rolling plains, is watered by the river Kaduna affluent of the River Niger and its main tributaries, and is greatly healthy and suitable for cultivation. The climate here for a great portion of the year is bracing, and in the cold season it is cold at night [16]. The 15 major farmlands understudy are Adamu, Hassan, Danjume, and Basiru farms located at Bomo village; Danja, Saleh, and Haruna farms located at Kwakwarmanu village; Abdulmumini and Iguda farms located at Sakadadi village; Mahammadu, Uba, and Aminu farms located at Dogarawa village; Dalhatu and Musa farms located at Maraban Gwanda village; and Safiano farm located at Gwanda village. 


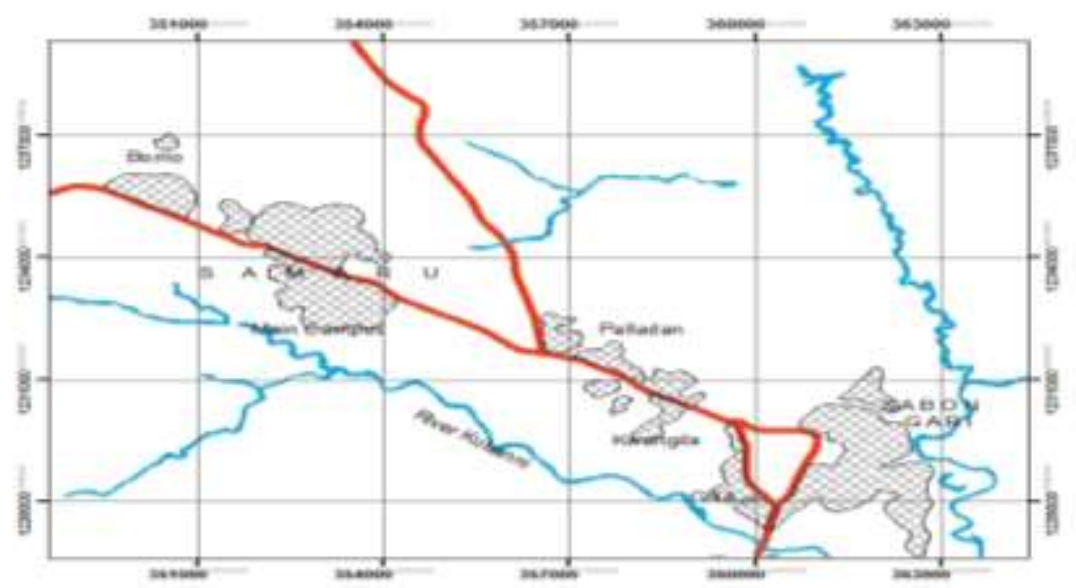

Fig. 1: Map showing study area

\section{Methodology}

The study entails the mapping of major farmlands (farmland area of 20 hectares or more) using GIS as an application. It is limited to 15 out of 21 farmlands in Sabon Gari local government area of Zaria in Kaduna state. The total size of farmlands under study is 649.42 hectares. A reconnaissance survey was carried out to have a general picture of the farmlands to be mapped and during the course of the reconnaissance; awareness was created among the farmers in Sabon Gari local government area about the purpose of the mapping project by interaction. The reconnaissance informed the decision on the choice of techniques employed in the course of data acquisition.

The data used in this study were obtained from two basic sources: primary data source- questionnaire distributed to the respondents (farmers) and a hand held GPS (GARMIN map 76S chart plotting receiver) for obtaining coordinates of waypoints; and secondary data source- a softcopy of the map (base map) of Sabon Gari local government area and neighboring local government areas obtained from the library of the Department of Geomatics Engineering, Ahmadu Bello University, Zaria.

The equipment available for this study include computers with ArcGIS 9.0 and Microsoft Access software installed on them and a hand held GPS (GARMIN map 76S chart plotting receiver)

The questionnaire was administered to each farmer to collect farm-related data such as farm name, farmer name, type of crop(s) that is (are) grown on each farm, etc. The whole map was digitized on-screen using ArcGIS 9.0 software. Three tables were created in Microsoft Access namely: attribute table of farmland, attribute table of farmland yield and coordinates of waypoints table. These tables were converted to dbase format for them to be recognized and used in ArcGIS 9.0. The table containing the $\mathrm{x}, \mathrm{y}$ coordinates was added to the map in ArcMap. Layers were created in ArcCatalogue using a personal Geodatabase. The layers created were roads, river, rail ways and farmlands.

The digitization of the raster data set was done using ArcGIS 9.0 software. In ArcMap, the tool used was the "editor tool". To start editing, the "start editing" was clicked and each of the layers was digitized using the "sketch tool". After the completion of digitization, the "finish sketch" was clicked, followed by "save edits", then "stop editing" was finally clicked.

The coordinates of points were stored separately in a notepad format in which they can be easily recognized in ArcGIS environment and using "add X, Y data" in the tools menu on the standard toolbar, the coordinates were plotted. The layer containing the coordinates plotted were exported into a shape file in order to allow an object ID to be assigned to them without which querying will be impossible. Thereafter, all the layers were merged.

Queries were carried out using the query builder. The query builder tool was clicked and a dialog box appeared. The query expression was built by either typing it in or clicking on the required fields, operators and values in the dialog box.

\section{Results \& Discussion}

The figures 2 and 3 below show the results of the query for farmlands with average annual yield greater than or equal to 0.6 ton per hectare and the spatial distribution of farmlands with average annual yield greater than 0.6 ton per hectare. Meanwhile, figures 4 and 5 show the results of query for farmlands that use River Kubani for irrigation and the spatial distribution of farmlands that use River Kubani for irrigation. 
5.1 Result of Query on Farmland Normal (Average) Annual Yield

\begin{tabular}{||r|r|}
\hline 围 Selected Attributes of Farmland \\
\hline Yrield.FARM_NAME & Yield.YIELD_IN_T \\
\hline HASSAN FARM & 0.62 \\
\hline DANJUME FARM & 0.72 \\
\hline BASIRU FARM & 0.77 \\
\hline DANJA FARM & 0.81 \\
\hline ABDULMUMINI FARM & 0.67 \\
\hline MAHAMMADU FARM & 0.87 \\
\hline DALHATU FARM & 0.76 \\
\hline UBA FARM & 0.7 \\
\hline IGUDA FARM & 0.65 \\
\hline AMINU FARM & 0.63 \\
\hline
\end{tabular}

Fig. 2: Farmlands with average annual yield greater than 0.6 ton per hectare

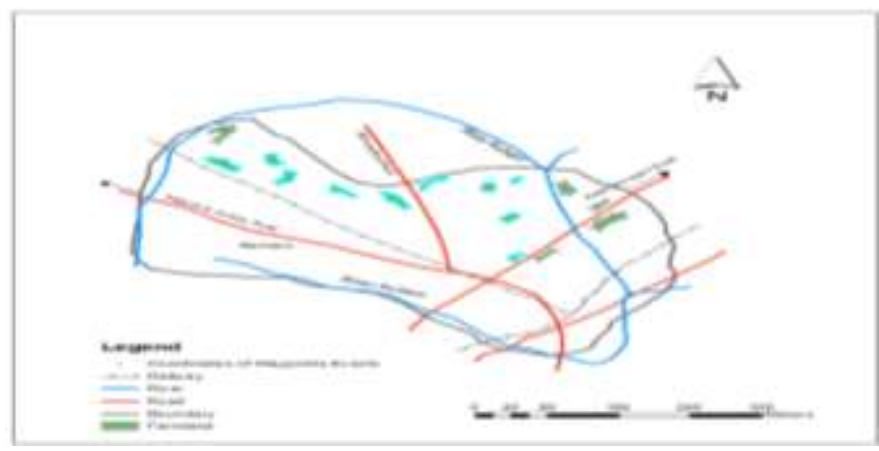

Fig. 3: Spatial distribution of farmlands with average annual yield greater than 0.6 ton per hectare

The yield per farmland is one of the ways of determining the productivity of a farmland. The average annual yield considered productive is 0.5 ton per hectare (minimum considered by agronomists to sustain human life), [5]. 0.6 ton per hectare was chosen to take care of any unbiasedness. From figures 2 and 3 it clearly shows that 12 farms have the capacity to produce crops to an appreciable quantity. However, some factors are responsible for a good yield such as rich soil, adequate farm inputs and extension work for promoting healthy and modern farming practices, and adequate irrigation.

Farming operations of all sizes use GIS to select the right growing regions for their crops and to design fields in ways that improve crop yield while saving money on fertilizers and water.

5.2 Result of Query on the Use of River Kubani for Irrigation

\begin{tabular}{|c|c|}
\hline Yield.FARM_IIAME & Attributes.IRRIGATION \\
\hline ADAMU FARII & RIVER KUBANI \\
\hline HASSAN FARII & RIVER KUBANI \\
\hline DANJUIME FARII & RIVER KUBANI \\
\hline BASIRU FARII & RIVER KUBANI \\
\hline SAFIANO FARII & RIVER KUBANI \\
\hline |MUSA FARII & RIVER KUBANI \\
\hline
\end{tabular}

Fig. 4: Farmlands that use River Kubani for irrigation

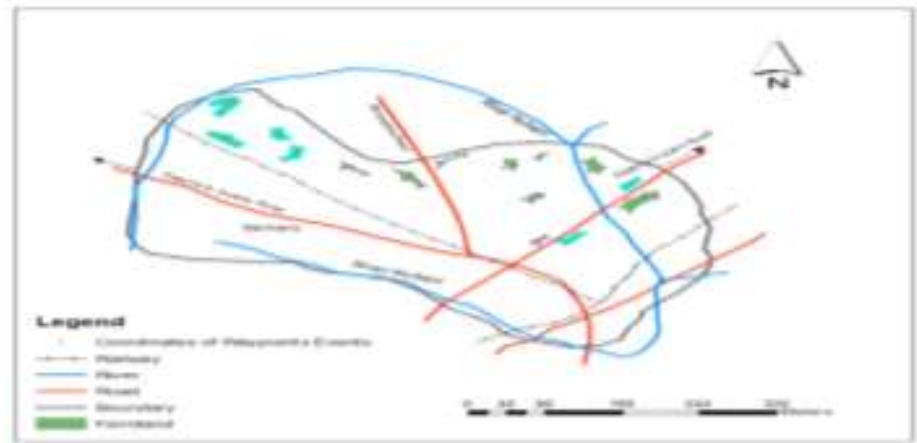

Fig. 5: Spatial distribution of farmlands that use River Kubani for irrigation 
Proper irrigation has always been one of the most crucial factors in successful agriculture. Not enough water results in sub-optimum crop yields as accessibility to a water source affects the output of a farm. From figures 4 and 5, it shows that River Kubani is a major source of irrigation for 6 farms (Adamu, Hassan, Danjume, Basiru, Safiano and Musa farms).

Table 1 shows the results of the queries conducted. Table 2, 3 and 4 show the distance analysis of farmlands to Kaduna-Sokoto, Kaduna-Kano and old Kano roads respectively. Table 5 indicates the distance analysis of farmlands to River Kubani. Table 6 indicates the distance analysis of farmlands to the railway.

\subsection{Analysis of Results of Queries}

TABLE 1: Results of Queries

\begin{tabular}{|l|l|l|}
\hline Theme of Query & Number & Percentage \\
\hline Number of farmlands in Bomo village & 4 & 26.67 \\
\hline Farmlands less than or equal to 50 hectares & 10 & 66.67 \\
\hline $\begin{array}{l}\text { Farmlands with average annual yield greater } \\
\text { than 0.6 ton per hectare }\end{array}$ & 12 & 80 \\
\hline Farmland that use River Kubani for irrigation & 6 & 40 \\
\hline $\begin{array}{l}\text { Farmlands with Guinea Corn output less than } \\
\text { 200 bags }\end{array}$ & 9 & 60 \\
\hline
\end{tabular}

From table 1, out of the 15 farmland that were mapped, four are located in Bomo village, indicating $26.67 \%$ of the farmland mapped. It also shows that 10 out of the 15 farmlands that were mapped have a land size of less than or equal to 50 hectares, representing $66.67 \%$ of the farmlands mapped. Meanwhile, it reveals that 12 farmlands have an average annual yield greater than 0.6 ton per hectare, indicating $80 \%$ of the 15 farmlands mapped. This means that the farmlands get an output of more than 8 bags $(8 \times 80 \mathrm{~kg})$ per hectare annually. Six 6 farmlands use the River Kubani as a major source of irrigation which represents $40 \%$ of the farmlands mapped. Finally, though not presented as a query result, it shows that 9 farmlands have an output of Guinea Corn less than 200 bags which represent $60 \%$ of the farmlands mapped.

5.4 Distance Analysis of Farmlands to Major Access Routes

TABLE 2: Distance Analysis of Farmland to Kaduna-sokoto Road

\begin{tabular}{|l|l|l|}
\hline Name of Farm & Approx. Distance $\mathbf{( K m )}$ & Description \\
\hline Hassan Farm & 0.32 & $\begin{array}{l}\text { Closest Farmland to Kaduna- } \\
\text { Sokoto Road }\end{array}$ \\
\hline
\end{tabular}

TABLE 3: Distance Analysis of Farmland to Kaduna-kano Road

\begin{tabular}{|l|l|l|}
\hline Name of Farm & Approx. Distance $\mathbf{( K m )}$ & Description \\
\hline Musa Farm & 0.15 & $\begin{array}{l}\text { Closest Farmland to Kaduna- } \\
\text { Kano Road }\end{array}$ \\
\hline
\end{tabular}

TABLE 4: Distance Analysis of Farmland to Old Kastina Road

\begin{tabular}{|l|l|l|}
\hline Name of Farm & Approx. Distance (km) & Description \\
\hline Mahammadu Farm & 3.99 & $\begin{array}{l}\text { Closest Farmland to Old } \\
\text { Katsina Road }\end{array}$ \\
\hline
\end{tabular}

TABLE 5: Distance Analysis of Farmlands to the Railway

\begin{tabular}{|l|l|l|l|}
\hline Name of Farm & Village & Approx. Distance $\mathbf{( K m )}$ & Description \\
\hline Hassan Farm & Bomo & 0.61 & $\begin{array}{l}\text { Closest Farmland to the Railway in } \\
\text { Bomo }\end{array}$ \\
\hline Abdulmumini Farm & Sakadadi & 3.00 & $\begin{array}{l}\text { Closest Farmland to the Railway in } \\
\text { Sakadadi }\end{array}$ \\
\hline Aminu Farm & Dogarawa & 2.11 & $\begin{array}{l}\text { Closest Farmland to the Railway in } \\
\text { Dogarawa }\end{array}$ \\
\hline
\end{tabular}

Access routes such as roads and railways are a major source of produce distribution and farm input acquisition. From table 2, the closest farmland to the Kaduna-Sokoto road is the Hassan farm with an approximate distance of $0.32 \mathrm{~km}(320 \mathrm{~m})$ while from table 3 the closest farmland to the Kaduna-kano road is the Musa farm with an approximate distance of $0.15 \mathrm{~km}(150 \mathrm{~m})$. Table 4 shows that Mahammadu farm is the closest farmland to the old Katsina road with an approximate distance of $3.99 \mathrm{~km}(3990 \mathrm{~m})$. According to table 5 , the closest farmland to the railway in Bomo village is Hassan farm which is $0.61 \mathrm{~km}(610 \mathrm{~m})$ away from the 
railway. The closest farmland to the railway in Sakadadi village is Abdulmumini farm which is $3 \mathrm{~km}(3000 \mathrm{~m})$ away from the railway while Aminu farm is the closest farmland to the railway in Dogarawa village which is about $2.11 \mathrm{~km}(2110 \mathrm{~m})$ away from the railway.

5.5 Distance Analysis of Farmlands to River Kubani

TABLE 6: Distance Analysis of Farmlands to River Kubani

\begin{tabular}{|l|l|l|l|}
\hline Name of Farm & Village & Approx. Distance (Km) & Description \\
\hline Adamu Farm & Bomo & 0.44 & $\begin{array}{l}\text { Closest Farmland to River } \\
\text { Kubani in Bomo }\end{array}$ \\
\hline Haruna Farm & Maraban Gwanda & 0.33 & $\begin{array}{l}\text { Closest Farmland to River } \\
\text { Kubani in Maraban } \\
\text { Gwanda }\end{array}$ \\
\hline
\end{tabular}

The proximity of farmlands to a major source of water for irrigation is an important factor that determines how well farmlands are irrigated. From table 6, the closest farmland to River Kubani in Bomo village is Adamu farm which is approximately $0.44 \mathrm{~km}(440 \mathrm{~m})$ away from the river and the closest farmland in Maraban Gwanda village to the same river is Haruna farm which is about $0.33 \mathrm{~km}(330 \mathrm{~m})$ away from the river.

\section{Conclusions}

This study presents a total of 15 major farmlands mapped out of the 21 farmlands in Sabon Gari local government area. This represents a $71.43 \%$ of the entire farmlands in the area. These farmlands studied are all located in or near villages with a total size of 649.2 hectares. The study identified farmland ownership, farmland yield, source of irrigation etc. Most of the farmlands mapped are less or equal to 50 hectares in size and with an average annual yield greater than 0.6 ton per hectare. Some farmlands are located near the River Kubani, which is a natural source of water for irrigating the farmlands. The relationship between the farmlands and the river can arguably be referred to as "Fadama". The study also shows that some farmlands are located close to some important roads and railways. These routes can be used as access and distribution venues for farm inputs (fertilizers, pesticides, etc.) and farm produce. Produce from these farmlands can be transported to the market through these routes. This study has created a database system that allows for easy access, storage and retrieval of farm-related information in the local government area.

The farmlands can be incorporated into the Fadama Development Project to help manage and control the information pertinent to the farmlands for their development as well as provision of food security. Information sharing should be encouraged in order to provide readily and timely information as well as help reduce the costs of obtaining information within the country as a whole.

\section{References}

[1] UNCTAD,Tacklingtheglobalfoodcrisis,2008.Retrievedfrom:www.unctad.org/tackling the_global_food_crisis. Accessed on 21-102008 21:25.

[2] J. Haskew, Food in burundi, International Federation of Red Cross and Red Crescent Societies, 2008.

[3] Wikipedia, World global food crisis, 2008. Retrieved from: http://en.wikipedia.org/wiki/world_global_food_crisis. Accessed on 1307-2008 11:51.

[4] S.B. Harsh, Agricultural information systems: Current applications and future prospects in agricultural information technology in Asia and Oceanic, 1996.

[5] K.P. Anup, C. Lim, P.S. Ramesh and K. Menas, Crop yield estimation model for IOWA using remote sensing and surface parameters. International Journal of Applied Earth Observation and Geoinformation, 8, 2006, 26-33

[6] M.J. Hayes and W.L. Decker, Using NOAA AVHRR data to estimate maize production in the United States Corn Belt. International Journal of Remote Sensing, 17, 1996, 3189-3200.

[7] M. Reynolds and D. Yittayew, Estimation of crop yields and production by integrating the FAO crop specific water balance model with real-time satellite data and ground-based ancillary data. International Journal of Remote Sensing, 21(18), 2000, 3487-3508.

[8] S. Sanaz and M. Valadanzouj, Assessment of crop yield estimation methods by using satellite images and ground observation, 2010. Retrieved from http://www.gisdevelopment.net/application/agriculture/yield/ma07106.html. Accessed on 23-08- 2010.

[9] P.F. Dale and J.D. McLaughlin, Land information management (Oxford: Clarendon Press, 1988).

[10] S. Aronoff, Geographic information system: a management perspective (Ottawa, Canada: WDL Publications, 1993).

[11] L. Lang, The role of GIS: Managing natural resources with GIS (New York: ESRI, 2005).

[12] K. Chang, Introduction to geographic information systems (New York: McGraw - Hill Companies, 2006).

[13] P. C. Nwilo and T. T. Youngu, Data discovery and metadata for the guinea current large marine ecosystem region. Nigerian Journal of Surveying \& Geoinformatics, 2(2), 2009, 17-33, 0189-8914

[14] P.H. Ezra and S.P. Olayiwola, GIS: A tool in the hand of a digital map maker (Kaduna: Oke International Ventures, 2005).

[15] N.F. Onukwu and, J.B. Olaleye, Automated topology building of vectorized spatial data. Department of Surveying \& Geoinformatics, University of Lagos, Lagos, 2006.

[16] Encyclopedia, Zaria, 2009. Retrieved from http//www.encyclopedia.jrank.org/yak_zym/zaria.html” $>$ zaria $</ a>$. Accessed on 11 10-2009. 